\title{
Сукупність принципів формування системи моніторингу і попередження військ (сил) про надзвичайні ситуації на потенційно-небезпечних об'єктах
}

\author{
Володимир Коваль ${ }^{\mathrm{A}}$; Євген Левіщенко ${ }^{\mathrm{B}}$
}

Received: June 2, 2020 | Revised: June 15, 2020 | Accepted: June 30, 2020

DOI: $10.33445 /$ sds.2020.10.3.14

\begin{abstract}
Анотація
У статті проаналізовано проблеми формування системи моніторингу і попередження військ (сил) про надзвичайні ситуації. Розкрито загальні принципи організації єдиної державної системи цивільного захисту, системи моніторингу та попередження про надзвичайні ситуації загальносистемних принципів побудови організаційно-технічних систем, аналізу відомих принципів військового управління, обґрунтуванню основних принципів розвитку систем управління.
\end{abstract}

Ключові слова: принципи, попередження, надзвичайні ситуації, система управління.

\section{Постановка проблеми}

Необхідність ведення операцій (бойових дій) на території із значною кількістю потенційно-небезпечних об'єктів (ПНО) вимагають чіткої організації заходів щодо моніторингу та попередження військ (сил) про надзвичайні ситуації на даних об'єктах [1]. У даному процесі важливу роль буде відігравати формування відповідної системи моніторингу і попередження військ (сил) про надзвичайні ситуації (СМПВНС) на ПНО.

Обґрунтоване формування СМПВНС на ПнО повинно ґрунтуватися на відповідних принципах, які $\epsilon$ осново утворюючими твердженнями для визначення раціонального варіанту такої системи [2-5]. Проте, на сучасному етапі розвитку організаційно-технічних систем теоретичні основи формування СМПВНС на ПНО розроблені недостатньо повно, у тому числі потребує уточнення питання щодо уточнення та доповнення сукупності основних принципів, яких необхідно дотримуватись для визначення раціонального варіанту СМПВНС на ПНО. Вказане і обумовлює актуальність розглянутої тематики.

\section{Аналіз останніх досліджень та публікацій}

Питанням дослідження принципів побудови організаційно-технічних систем присвячена певна кількість наукових робіт [110]. Дані роботи присвячені розкриттю загальних принципів організації єдиної державної системи цивільного захисту [1], системи моніторингу та попередження про надзвичайні ситуації [3] загальносистемних принципів побудови організаційно-технічних систем [4, 5], аналізу відомих принципів військового управління [6], обґрунтуванню основних принципів розвитку систем управління [7-10]. Проведений аналіз наведених джерел дозволяє зробити висновок, що сформульовані напрацювання не повною мірою дозволяють сформувати сукупність принципів, необхідних для визначення раціонального варіанту СМПВНС

\footnotetext{
А Воєнно-наукове управління Генерального штабу Збройних Сил України, начальник управління, к.в.н., старший науковий співробітник, е-таі: vladimerkoval69@gmail.com, ORCID: 0000-0002-6209-6779

в Воєнно-наукове управління Генерального штабу Збройних Сил України, начальник відділу, e-mail: lev1753@ukr.net, ORCID: 0000-0001-8166-0577
} 


\begin{tabular}{lllll}
\hline на ПнО. Тому метою сmammi & систематизація принципів & визначення \\
формулювання, & класифікація & та & раціонального варіанту СМПВНС на ПНО.
\end{tabular}

\section{Виклад основного матеріалу}

Створення ефективних організаційнотехнічних СМПВНС на ПнО в сьогоднішніх умовах можливе за рахунок [1]:

завчасного створення і підтримання в постійній готовності до застосування системи попередження військ про надзвичайні ситуації на Пно;

своєчасного розгортання складових елементів системи моніторингу та попередження військ (сил) про надзвичайні ситуації на ПнО;

завчасного визначення вимог щодо доведення інформації від технічних засобів моніторингу про надзвичайні ситуації на ПНО до військ (сил).

Виконання вказаних заходів можливе за рахунок дотримання певних принципів, які являють собою загальні науково обґрунтовані положення, правила, рекомендації щодо дій для досягнення визначеної мети $[5,9,10]$.

3 урахуванням того, що СМПВНС на ПНО відноситься до складної організаційнотехнічної системи, для неї необхідно визначити вихідні положення щодо базових правил побудови складових елементів цієї системи (підсистеми управління силами та технічними засобами моніторингу та попередження військ (сил); підсистеми сил та технічних засобів моніторингу надзвичайних ситуацій на ПНО; сил та технічних засобів попередження військ (сил) про надзвичайні ситуації на ПнО; ресурсного забезпечення функціонування системи), застосування яких спрямоване на збереження спроможностей військ (сил) в умовах виникнення надзвичайної ситуації на ПНО.

Результати досвіду застосування 3бройних Сил України на сході нашої держави $[1,11]$, дозволяють визначити основні особливості застосування військ (сил) в умовах виникнення надзвичайних ситуацій на ПнО:

зростання кількості надзвичайних ситуацій на ПНО до яких, насамперед, відносяться радіаційно-небезпечні, хімічно-небезпечні, біологічно-небезпечні, вибухо- та пожежонебезпечні та гідродинамічнонебезпечні об'єкти;

спільне виконання завдань щодо моніторингу та попередження військ (сил) про надзвичайні ситуації на ПНО в загальній державній системі цивільного захисту, яка не в повній мірі адаптована до застосування в умовах ведення операцій (бойових дій);

низькі спроможності територіальних функціональних підсистем моніторингу та попередження про надзвичайні ситуації на ПнО державної системи цивільного захисту, структури яких в більшості випадків не готові до спільного виконання завдань 3 військовими організаційними структурами Збройних Сил України;

низький рівень організації взаємодії СМПВНС на ПНО з аналогічними системами складових сил безпеки та оборони держави.

Вказані особливості та досвід формування СМПВНС на ПНО [1] та інших організаційнотехнічних систем [4, 8-10] дозволяє визначити сукупність структурно-організаційні принципів формування системи, принципів формування варіантів системи та принципів ії розгортання.

3 урахуванням особливостей побудови СМПВНС на ПнО як багаторівневої ієрархічної системи можна сформулювати такі основні структурно-організаційні принципи ії формування:

цілеобумовленості - для досягнення мети системи повинна формуватися належним чином організована сукупність сил і технічних засобів управління, моніторингу та попередження;

відносності - одна і та ж сукупність сил і технічних засобів управління, моніторингу та попередження може розглядатися як самостійна складова, так і як складова іншої сукупності сил і засобів управління, моніторингу та попередження. Даний принцип обумовлює необхідність під час 
визначення доцільної структури об'єднання технічних засобів управління, моніторингу та попередження, упорядковувати їх за відповідними рівнями;

адаптивності - $з$ урахуванням високої динамічності розвитку надзвичайної ситуації структура об'єднання сил і технічних засобів управління, моніторингу та попередження у відповідну систему повинна бути адаптивною, тобто здатною змінюватися в залежності від умов функціонування системи. Така зміна може відбуватися шляхом зміни кількості сил і технічних засобів управління, моніторингу та попередження та зв'язків між ними тощо;

оперативності - швидкий та динамічний розвиток надзвичайних ситуацій на ПНО приводить до необхідності обов'язкового врахування фактор часу під час синтезу структури об'єднання сил і технічних засобів управління, моніторингу та попередження;

відповідності організаційної структури об'єднання управління, моніторингу та попередження - виконання даного принципу генерує чітку організацію взаємодії сил і засобів під час комплексного вирішення завдань моніторингу та попередження військ (сил) про надзвичайні ситуації на ПНО.

До основних принципів формування варіантів СМПВНС на ПНО необхідно віднести принципи:

ефрективності - раціональне співвідношенні між отриманим ефектом від функціонування системи та витратами на формування її складу. При цьому обов'язково проводиться аналіз можливих варіантів формування системи за результатами якого обирається варіант 3 найменшими витратами;

комплексності - створення раціональної системи можливе у разі визначення комплексу сил і технічних засобів управління, моніторингу та попередження;

відповідності - склад сил і технічних засобів управління, моніторингу та попередження повинні відповідати складу і структурі угруповання військ (сил) в інтересах якого розгортається система;

інтегрованості - система повинна мати можливість інтегруватися у загальну систему ліквідації наслідків надзвичайних ситуацій на ПНО.

В умовах ведення операцій (бойових дій) $\epsilon$ висока ймовірність навмисного або супутнього зруйнування ПнО. У таких умовах виникає необхідність дотримання нового принципу забезпечення доцільного рівня безпеки військ (сил) - система повинна розгортати таку кількість сил і технічних засобів управління, моніторингу та попередження, які забезпечують збереження спроможностей військ (сил) в умовах виникнення надзвичайної ситуації на ПНО. При цьому потрібно враховувати, що рівень небезпеки від надзвичайної ситуації на ПнО не $\epsilon$ сталим і залежить від фізикогеографічних та і кліматичних умов, стану забезпеченості військ (сил) засобами і системами захисту, рівня підготовленості особового складу тощо.

До основних принципів розгортання СМПВНС на ПНО відносяться принципи:

дочільності - під час вибору технічних засобів моніторингу та попередження для розгортання СМПВНС на ПНО перевага надається засобам, які забезпечують найбільшу ефективність;

сумісності - визначення єдиних підходів до застосування різновидових та різновідомчих сил та технічних засобів СМПВНС на Пно;

взаємодї-комплексування сил і технічних засобів для досягнення заданого ефекту моніторингу та попередження військ (сил) про надзвичайні ситуації на ПНО.

Ефективне функціонування СМПВНС на ПнО можливе за умови удосконалення підсистеми управління силами і технічними засобами управління, моніторингу та попередження. 3 урахуванням положень викладених у [8-10] удосконалення даної підсистеми за рахунок впровадження мережецентричних принципів управління шляхом створення горизонтальних зв'язків між пунктами збору даних моніторингу та пунктами управління системи через відповідні автоматизовані системи управління. 
Це обумовлює доцільність впровадження нового принципу управління силами і технічними засобами управління, моніторингу та попередження - принципу управління у єдиному просторі. Зазначений принцип передбачає створення єдиного інформаційно-комунікаційного простору шляхом об'єднання розвідувальних та інформаційних мереж, органів і пунктів управління, засобів моніторингу та попередження.

Удосконалена сукупність принципів формування СМПВНС на ПНО наведена на малюнку.

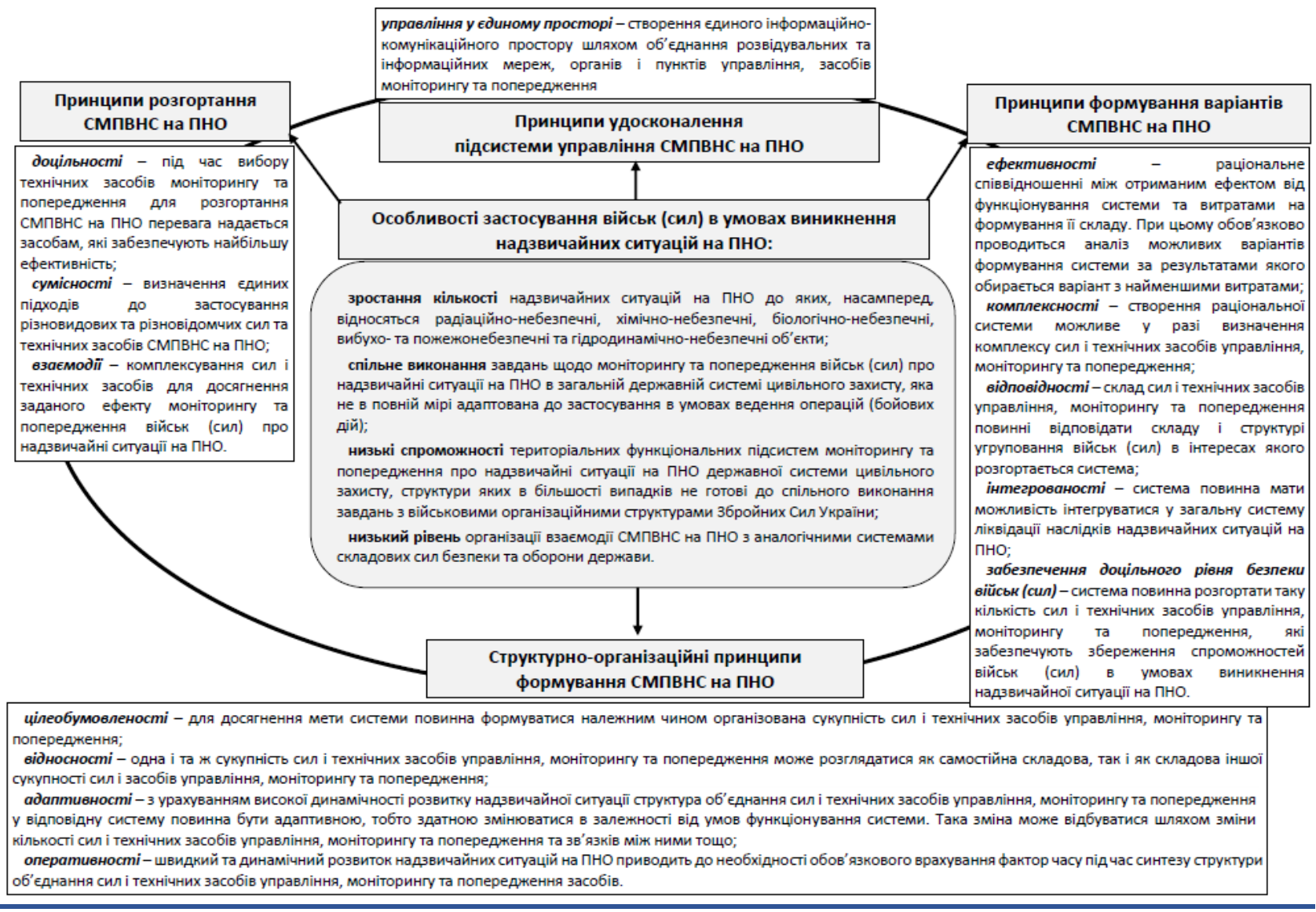

Малюнок - Сукупність принципів формування СМПВНС на ПНО

\section{Висновки}

Таким чином, сформульовані принципи формування раціонального варіанту СМПВНС на ПнО, які ґрунтуються на загальних принципах формування організаційнотехнічних систем, особливостях дій військ (сил) в умовах надзвичайних ситуацій, та, додатково враховує принципи забезпечення безпеки та управління у єдиному просторі. Напрямом подальшого дослідження $\epsilon$ розроблення концепції формування СМПВНС на Пно та обґрунтування сукупності показників і критеріїв для визначення ї̈ раціонального варіанту.

\section{Список використаних джерел}

1. Михайлова А.В. Система моніторингу та попередження про надзвичайні ситуації в зоні проведення операції об'єднаних сил: дис.канд.тех.наук: 21.02.03. Київ, 2020. $236 \mathrm{c}$.
2. Стрижевський В. В., Музиченко Д. П. Надзвичайні ситуації природного та техногенного характеру. Участь формувань сухопутних військ збройних сил України у ліквідації наслідків надзвичайних ситуації 
природного та техногенного характеру: навч. посіб. Київ: НАОУ, 2007. 58 с.

3. Гречанінов В. Ф. Рекомендації щодо функціонування єдиної державної системи цивільного захисту в умовах (перша редакція) / В. Ф. Гречанінов /Укр. наук.дослід. ін-т цивіл. захисту. - URL: http://undicz.dsns.gov.ua/files/2016/8/30.

4. Проектування організаційних структур: методи і алгоритми / Герасимов В. І., Рабчук О. А. Київ: БФ “Миротоворець", 2000. 206 c.

5. Тараканов К. В. Математика и вооружённая борьба. Москва: Воениздат, 1974. 240 с.

6. Сбітнєв, А. І. Принципи військового управління та військового мистецтва базис сучасної науки. Сучасні інформаційні технології у сорері безпеки та оборони. 2008. № 1 (1). С. 42-49.

7. Загорка О. М., Коваль В. В., Тюрін В. В., Малюга В. Г., Загорка І. О. Особливості та принципи побудови мережецентричної системи управління угруповання військ (сил). Збірник наукових праць Харківського національного університету Повітряних Сил. 2016. № 3 (48). С. 7-11.

8. Ярош С. П. Теоретичні основи побудови та застосування розвідувально-управляючих інформаційних систем протиповітряної оборони: монографія. Харків: ХУПС, 2012. 512 c.

9. Ткаченко В. І., Смірнов Є. Б. та ін. Теорія прийняття рішень органами військового управління: многорафія. Харків: ХУПС, 2008. 545 c.

10. Смірнов Є. Б., Ткаченко В. І., Рубан І. В., Малюга В. Г., Тристан А. В. Теоретичні основи формування та деградації складних організаційно-технічних систем: монографія. Харків: ФОП Панов А.М., 2018. $162 \mathrm{c}$.

11. Інформаційні матеріали до 5-річчя від початку збройної агресії Російської Федерації проти України. URL: https://uinp.gov.ua/informaciyni-materialy/ viyskovym/do-5-richchya-vid-pochatkuzbroynoyi-agresiyi-rosiyskoyi-federaciyiproty-ukrayiny.

\title{
Совокупность принципов формирования системы мониторинга и предупреждения войск (сил) о чрезвычайных ситуациях на потенциально опасных объектах
}

\author{
Владимир Коваль ${ }^{\text {; } ; ~ Е в г е н и и ̆ ~ Л е в и щ е н к о ~}{ }^{\mathrm{B}}$ \\ А Военно-научное управление Генерального штаба Вооруженных Сил Украины, начальник управления, к.в.н., старший \\ научный сотрудник, e-mail: vladimerkoval69@gmail.com, ORCID: 0000-0002-6209-6779 \\ в Военно-научное управление Генерального штаба Вооруженных Сил Украины, начальник отдела, e-mail: lev1753@ukr.net, \\ ORCID: 0000-0001-8166-0577
}

\begin{abstract}
Аннотация
В статье проанализированы проблемы формирования системы мониторинга и предупреждения войск (сил) о чрезвычайных ситуациях. Раскрыты общие принципы организации единой государственной системы гражданской защиты, системы мониторинга и предупреждения о чрезвычайных ситуациях общесистемных принципов построения организационно-технических систем, анализа известных принципов военного управления, обоснованию основных принципов развития систем управления.
\end{abstract}

Ключевые слова: принципы, предупреждение, чрезвычайные ситуации, система управления.

\section{A set of principles for the formation of a monitoring system and warning of troops (forces) about emergencies at potentially dangerous objects}




\title{
Volodymyr Koval ${ }^{A}$; Evgen Levischenko ${ }^{B}$ \\ A Military-Scientific Department of the General Staff of the Armed Forces of Ukraine, Head of the Department, Ph.D., senior researcher, e-mail: vladimerkoval69@gmail.com, ORCID: 0000-0002-6209-6779

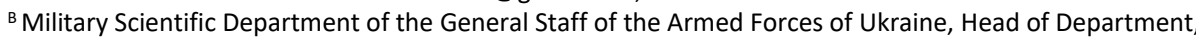 e-mail: lev1753@ukr.net, ORCID: 0000-0001-8166-0577
}

\begin{abstract}
The article analyzes the problems of forming a monitoring system and warning troops (forces) about emergencies. There are the general organization principles of civil defense the unified state system, a monitoring system and warning of system-wide principles emergencies of organizational construction and technical systems, known principles analysis of military management, substantiation of management systems basic principles are revealed.
\end{abstract}

Keywords: principles, warnings, emergencies, management system.

\section{References}

1. Mikhailova A. V. Monitoring and warning system for emergencies in the area of the joint forces operation: Candidate of Technical Sciences: 21.02.03. Kyiv, 2020. 236 p. [in Ukraine]

2. Stryzhevsky V. V., Muzychenko D. P. Emergencies of natural and man-made nature. Participation of formations of land troops of the Armed Forces of Ukraine in liquidation of consequences of emergencies of natural and technogenic character: textbook. way. Kyiv: NAOU, 2007. 58 p.

3. Grechaninov VF Recommendations for the functioning of a single state system of civil protection in terms (first edition) / VF Grechaninov / Ukr. research int civilians. protection. URL: http://undicz.dsns.gov.ua/ files/2016/8/30.

4. Design of organizational structures: methods and algorithms / Gerasimov VI, Rabchuk OA Kyiv: Charitable Foundation "Myrotovorets", 2000. 206 p.

5. Tarakanov K. V. Mathematics and armed struggle. Moscow: Military Publishing, 1974. $240 \mathrm{p}$.

6. Sbitnev, A. I. (2008) Principles of military management and military art - the basis of modern science. Modern information technologies in the field of security and defense. № 1 (1). Pp. 42-49.

7. Zagorka O. M., Koval V. V., Tyurin V. V., Malyuga V. G., Zagorka I. O. Peculiarities and principles of construction of network-centric control system of grouping of troops (forces). Collection of scientific works of Kharkiv National University of the Air Force. 2016. №3 (48). Pp. 7-11.

8. Yarosh S. P. Theoretical bases of construction and application of reconnaissance and control information systems of air defense: monograph. Kharkiv: HUPS, 2012. 512 p.

9. Tkachenko V. I., Smirnov E. B. etc. Theory of decision-making by military authorities: a monograph. Kharkiv: HUPS, 2008. 545 p.

10. Smirnov E. B., Tkachenko V. I., Ruban I. V., Malyuga V. G., Tristan A. V. Theoretical bases of formation and degradation of complex organizational and technical systems: monograph. Kharkiv: FOP Panov A. M., 2018. $162 \mathrm{p}$.

11. Information materials to the 5th anniversary of the beginning of the armed aggression of the Russian Federation against Ukraine. URL: https://uinp.gov.ua/informaciynimaterialy/viyskovym/do-5-richchya-vidpochatku-zbroynoyi-agresiyi-rosiyskoyifederaciyi-proty-ukrayiny. 